\title{
Cellulolytic Enzymes in Culture Filtrates of Rhizoctonia lamellifera
}

\author{
By P. O. OLUTIOLA \\ Division of Microbiology, Biology Department, University of Ife, Nigeria
}

(Received 14 July 1976)

\begin{abstract}
SUMMARY
During growth in a liquid culture containing a single soluble or an insoluble cellulosic carbon source, Rhizoctonia lamellifera released cellulolytic enzymes into the medium. These enzymes were separated by gel filtration and ion-exchange chromatography into seven components, three of high and four of low molecular weight. One of the components had the character of a $C_{1}$ cellulase. When the components were combined they released more reducing sugars from cellulosic substrates than when used singly.
\end{abstract}

\section{INTRODUCTION}

Rhizoctonia lamellifera penetrates healthy roots, causing a rapid degeneration of both cortical and vascular tissues (Small, 1928), and is associated with the blast disease of the oil palm (Elaeis guineensis) in Nigeria (Robertson, 1959). Many plant pathogens produce a distinct $C_{1}$ cellulase which hydrolyses crystalline forms of cellulose to soluble polyanhydroglucose chains which can be degraded by other cellulolytic enzymes $-C_{x}$ cellulase and cellobiase. Such a complex of cellulase enzymes has been isolated from other fungi (Wood, I968; Whitney, Chapman \& Heale, 1969; Olutiola \& Ayres, 1973). This paper describes the production of cellulolytic enzymes by laboratory cultures of $R$. lamellifera, the composition and activity of this enzyme system and the growth of the fungus on celluloses.

\section{METHODS}

Organism and culture conditions. Rhizoctonia lamellifera (NIFOR-24.9.74) was obtained from the culture collection of the Nigerian Institute for Oil Palm Research, Benin, Nigeria. Stock cultures were maintained on $\mathrm{I} \%(\mathrm{w} / \mathrm{v})$ malt extract agar slants. Cultures were grown in a basal medium containing $29.4 \mathrm{mM}-\mathrm{NaNO}_{3}, 7 \cdot 3 \mathrm{mM}^{-\mathrm{KH}_{2}} \mathrm{PO}_{4}$, I mM- $\mathrm{MgSO}_{4} \cdot 7 \mathrm{H}_{2} \mathrm{O}, 29 \mu \mathrm{M}-$ $\mathrm{CaSO}_{4} \cdot 2 \mathrm{H}_{2} \mathrm{O}$, I8 $\mu \mathrm{M}-\mathrm{FeSO}_{4} \cdot 7 \mathrm{H}_{2} \mathrm{O}, \mathrm{I} 5.7 \mu \mathrm{M}-\mathrm{MnSO}_{4} .4 \mathrm{H}_{2} \mathrm{O}, 20 \mu \mathrm{M}-\mathrm{CuSO}_{4} .2 \mathrm{H}_{2} \mathrm{O}, 3.5 \mu \mathrm{M}-$ $\mathrm{ZnSO}_{4} \cdot{ }_{7} \mathrm{H}_{2} \mathrm{O}, 3.0 \mu \mathrm{M}$-thiamin and $0.04 \mu \mathrm{M}$-biotin: all chemicals were analytical reagent grade. The carbon source was usually I \% (w/v) carboxymethylcellulose (CM-cellulose). Other carbon sources used were cellulose powder (Difco), Whatman no. I filter paper and viscose cellulose (Gallenkamp). Cultures were grown in $250 \mathrm{ml}$ flasks containing $100 \mathrm{ml}$ liquid medium. Each flask was inoculated with $\mathrm{I} \mathrm{ml}$ of an aqueous spore suspension prepared from a 6-day-old agar slant culture, and incubated at $30^{\circ} \mathrm{C}$ without shaking.

Preparation of enzyme solution. After incubation for 7 days (unless otherwise stated) stationary phase cultures were filtered through a glass-fibre filter (Whatman GF/A), and the reducing sugars and protein content of the filtrate were measured by the techniques of Miller (I959) and Lowry et al. (195I) respectively. The filtrate was then concentrated to about $12 \%$ of its original volume in a rotary vacuum evaporator at $37^{\circ} \mathrm{C}$ (Selby \& Maitland, 1967; 
Whitney et al., 1969) and low molecular weight substances were removed by mixing with dry Sephadex G-25 for 10 min (Flodin, Gelotte \& Porath, 1960). The concentrate was sterilized by membrane filtration (Oxoid) before fractionation and assay. The mycelium, retained on the filter, was rinsed with distilled water to free it from medium components, dried in an oven at $80^{\circ} \mathrm{C}$ for $12 \mathrm{~h}$ and weighed.

Fractionation on Sephadex G-75. A column $(700 \times 25 \mathrm{~mm})$ of Sephadex G-75 was prepared according to Whitaker (1963) and Andrews (1964) and was surrounded by a water jacket at $20^{\circ} \mathrm{C}$. Concentrated culture filtrate ( $10 \mathrm{ml}$ ) was applied to the column and eluted with a phosphate buffer (pH 6.5) containing 6.7 mM- $\mathrm{NaH}_{2} \mathrm{PO}_{4}$, IOO mM-NaCl, $3.3 \mathrm{mM}-\mathrm{Na}_{2} \mathrm{HPO}_{4}$

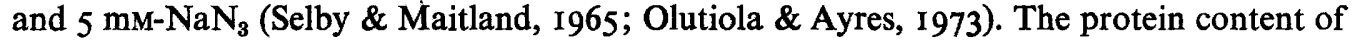
the eluted fractions $(2.6 \mathrm{ml})$ was recorded by continuous measurement of the extinction at $280 \mathrm{~nm}$ and appropriate fractions were collected automatically. The fractions were also examined for activity towards CM-cellulose, cellobiose and insoluble cellulose powder. The Sephadex column was calibrated using ferritin (mol. wt 480000), calf catalase (mol. wt 240000), aldolase (mol. wt 147000), bovine serum albumin (mol. wt 67000), egg albumin (mol. wt 45000), myoglobin (mol. wt 17800 ), cytochrome $c$ (mol. wt 12400 ), and DNP-Lalanine (mol. wt 255.2) which were obtained from Serva-Feinbiochemica (D-69 Heidelberg I, Germany).

Fractionation by ion-exchange chromatography. After gel filtration, each series of fractions corresponding to an absorption peak at $280 \mathrm{~nm}$ was combined and concentrated to about $4 \mathrm{ml}$ in a rotary evaporator, and made up to $\mathrm{I} 0 \mathrm{ml}$ in $0.09 \mathrm{M}$-sodium succinate buffer $(\mathrm{pH} 5 \cdot 2)$

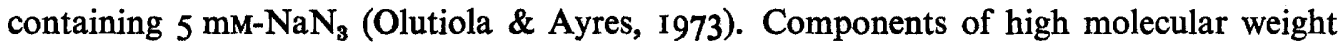
(peak A fractions) were applied to a column of CM Sephadex C-50; those of lower molecular weight (peak B fractions) were applied to a column of CM Sephadex C-25. Each column $(400 \times 30 \mathrm{~mm})$ was surrounded by a water jacket at $20^{\circ} \mathrm{C}$ and eluted with sodium succinate buffer ( $\mathrm{pH} 5 \cdot 2)$. Fractions $(2.6 \mathrm{ml})$ were collected and assayed as described for Sephadex G-75 columns.

Enzyme assays. Cellulase and cellobiase activities were determined by measuring the reducing sugars released in reaction mixtures. The reaction mixtures, containing $0.5 \mathrm{ml}$ enzyme preparation and $0.5 \mathrm{ml} \mathrm{CM}$-cellulose (I \%, w/v) or cellobiose $\left(0.7 \mathrm{mg} \mathrm{ml}^{-1}\right)$ in citrate/phosphate buffer ( $\mathrm{pH} 5.5)$, were incubated at $30^{\circ} \mathrm{C}$ for $2 \mathrm{~h}$. The reducing sugars released were measured by the technique of Miller (1959). The unit of activity (u.) is defined as the amount of enzyme in I $\mathrm{ml}$ of reaction mixture that liberates reducing sugar equivalent to Io $\mu \mathrm{g}$ glucose.

Cellulase activity was also monitored in an Ostwald viscometer (British Standard Units, size C) containing $5 \mathrm{ml}$ enzyme solution and $5 \mathrm{ml} \mathrm{I} \% \mathrm{CM}$-cellulose in citrate/phosphate buffer ( $\mathrm{pH} 5.5)$ at $30^{\circ} \mathrm{C}$ for $\mathrm{I} \mathrm{h}$.

The activity of the protein fractions towards insoluble cellulose powder (Difco) was measured, singly and in combination, by incubating $5 \mathrm{mg}$ cellulose, $1 \mathrm{ml}$ citrate/phosphate buffer ( $\mathrm{pH} 5.5$ ), $0.5 \mathrm{ml}$ enzyme solution and $5 \mathrm{mM}-\mathrm{NaN}_{3}$ for 7 days at $35^{\circ} \mathrm{C}$ (Olutiola \& Ayres, 1973). The unhydrolysed cellulose was then removed by membrane filtration and the filtrate was analysed for glucose using the $o$-toluidine reagent of Wootton (1964).

\section{RESULTS}

In blast disease of the oil palm, $R$. lamellifera is associated with roots showing cortical decay. Extracts obtained by grinding such infected tissues in $0.1 \mathrm{M}$-phosphate buffer (pH 5.5 ), and clarified by centrifuging at $10000 \mathrm{~g}$ for $\mathrm{I} 5 \mathrm{~min}$ at $4{ }^{\circ} \mathrm{C}$, showed only very slight activity 


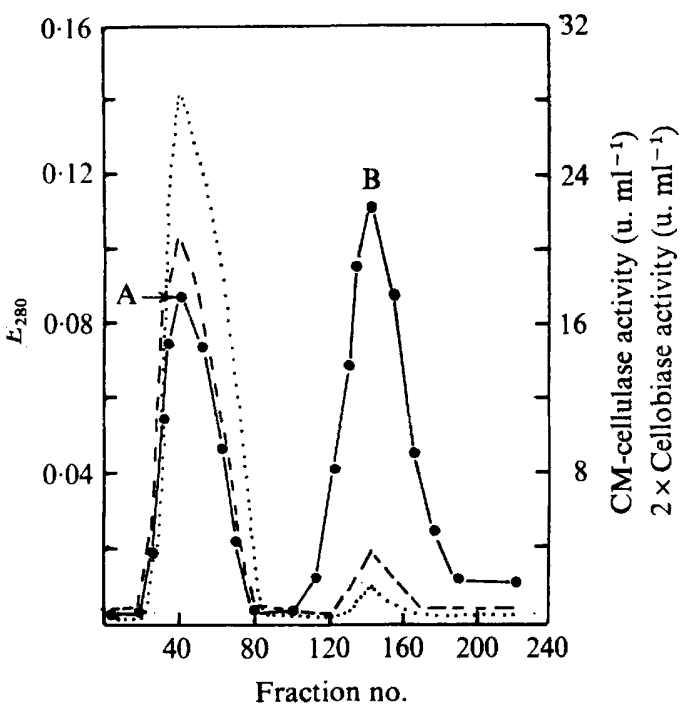

Fig. I

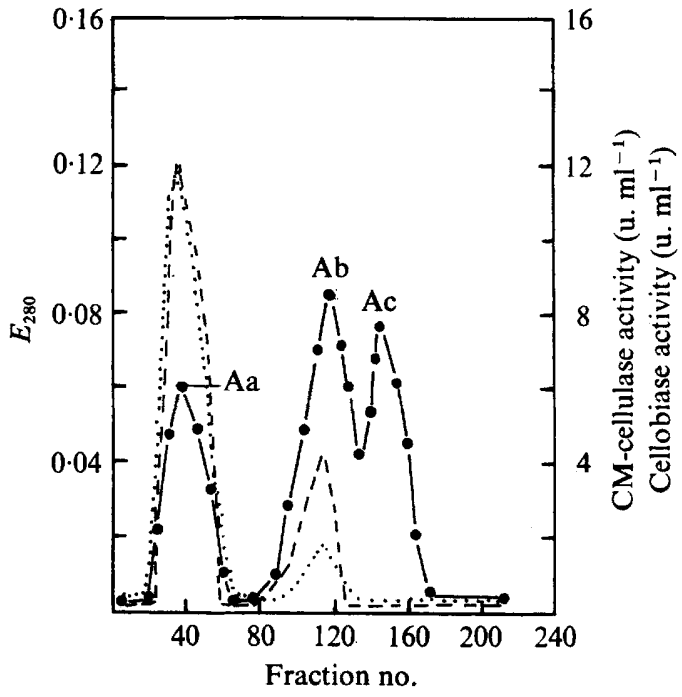

Fig. 2

Fig. I. Separation of proteins in concentrated culture filtrates of $R$. lamellifera by gel filtration, and enzymic activity of the fractions towards CM-cellulose and cellobiose. - , Protein $\left(E_{280}\right)$; --- , CM-cellulase activity; $\cdots$, cellobiase activity.

Fig. 2. Separation by ion-exchange chromatography of high molecular weight proteins (fractions 30 to 68 separated from culture filtrates of $R$. lamellifera by gel filtration; Fig. I), and enzymic activity of the fractions towards CM-cellulose and cellobiose. - , Protein $\left(E_{280}\right)$; - - , CMcellulase activity; $\cdots$, cellobiase activity.

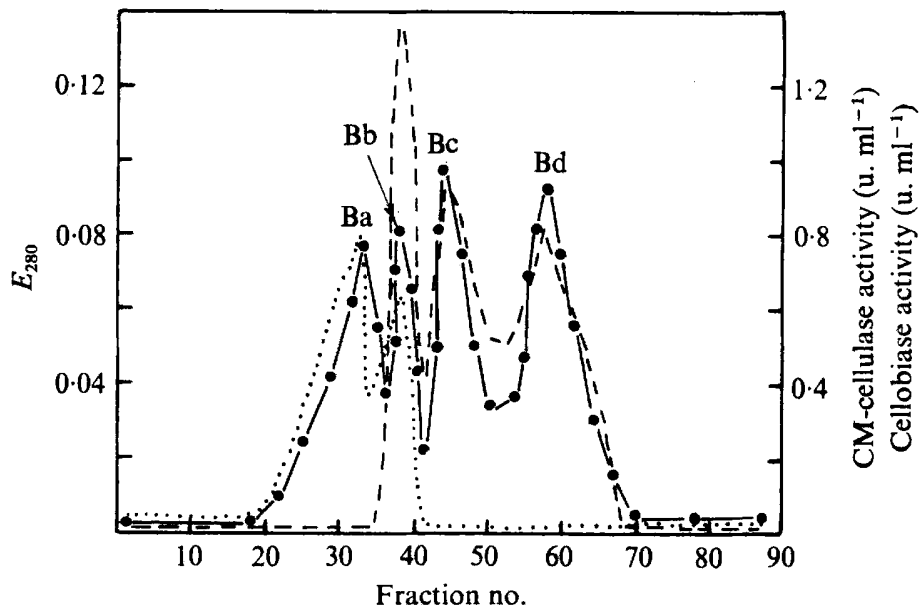

Fig. 3. Separation by ion-exchange chromatography of low molecular weight proteins (fractions 128 to 166 separated from culture filtrates of $R$. lamellifera by gel filtration; Fig. I), and enzymic activity of the fractions towards $\mathrm{CM}$-cellulose and cellobiose. $\longrightarrow$, Protein $\left(E_{280}\right) ;---$, CMcellulase activity; $\cdots$, cellobiase activity. 
Table 1. Enzymic activity towards insoluble cellulose of components separated from culture filtrates of Rhizoctonia lamellifera by gel filtration and ion-exchange chromatography

Enzyme activity is expressed as the glucose equivalent of reducing sugars $\left(\mu \mathrm{g} \mathrm{ml}^{-1}\right)$ released from cellulose powder.

\begin{tabular}{|c|c|c|}
\hline Means of separation & Components & $\begin{array}{l}\text { Glucose equ } \\
\text { of reducing sugar }\end{array}$ \\
\hline None & Concentrated culture filtrate & 7I \\
\hline phadex G-75 & $\begin{array}{l}\mathbf{A} \\
\mathbf{B} \\
\mathbf{A}+\mathbf{B}\end{array}$ & $\begin{array}{l}32 \\
25 \\
69\end{array}$ \\
\hline phadex C-50 of component A & $\begin{array}{l}\mathrm{Aa} \\
\mathrm{Ab} \\
\mathrm{Ac} \\
\mathrm{Aa}+\mathrm{Ab} \\
\mathrm{Aa}+\mathrm{Ac} \\
\mathrm{Ab}+\mathrm{Ac} \\
\mathrm{Aa}+\mathrm{Ab}+\mathrm{Ac}\end{array}$ & $\begin{array}{l}5 \cdot 6 \\
7 \cdot 1 \\
8 \\
12 \\
20 \\
23 \\
31\end{array}$ \\
\hline phadex C-25 of component B & $\begin{array}{l}\mathrm{Ba} \\
\mathrm{Bb} \\
\mathrm{Bc} \\
\mathrm{Bd} \\
\mathrm{Ba}+\mathrm{Bb} \\
\mathrm{Ba}+\mathrm{Bc} \\
\mathrm{Ba}+\mathrm{Bd} \\
\mathrm{Bb}+\mathrm{Bc} \\
\mathrm{Bb}+\mathrm{Bd} \\
\mathrm{Bc}+\mathrm{Bd} \\
\mathrm{Ba}+\mathrm{Bb}+\mathrm{Bc}+\mathrm{Bd}\end{array}$ & $\begin{array}{l}11 \\
6 \cdot 5 \\
8 \\
5 \\
16 \\
20 \\
15 \\
17 \\
10 \\
14 \\
23\end{array}$ \\
\hline
\end{tabular}

in reducing the viscosity of buffered I \% (w/v) CM-cellulose; thus it was difficult to extract adequate quantities of active enzyme for laboratory work. However the organism grew rapidly in artificial media (producing white mycelia which finally turned black as abundant sclerotia were produced) and so laboratory cultures were used in the present work.

Growth on cellulosic substrates and enzymic activity of culture filtrates. Rhizoctonia lamellifera grew on CM-cellulose, cellulose powder, Whatman no. I filter paper and viscose cellulose when each was used as the sole carbon source. The ability of the organism to hydrolyse CM-cellulose was shown by a noticeable decrease in the viscosity of the medium and by an increase in cell mass which corresponded to the measured increase in the concentration of reducing sugars liberated into the medium.

Culture filtrates reduced the viscosity of buffered CM-cellulose solution, with an accompanying release of reducing sugars, over a wide range of $\mathrm{pH}$ values with an optimum at pH 5.5. They also showed cellobiase activity, liberating glucose from cellobiose (Fig. 1).

Fractionation on Sephadex G-75. Fractionation of the concentrated culture filtrate on Sephadex G-75 led to two absorption peaks designated A and B (Fig. 1). The molecular weights of the components of these peaks, estimated from their elution volumes, were approximately 89100 and 9600 respectively.

Fractionation on $C M$ Sephadex $C$-50 and $C$-25. Fractionation of component A on Sephadex C-50 gave three absorption peaks designated $\mathrm{Aa}, \mathrm{Ab}$ and $\mathrm{Ac}$ (Fig. 2). Fractionation of component B on Sephadex C-25 gave four peaks, Ba, Bb, Bc and Bd (Fig. 3).

Components $\mathrm{Aa}, \mathrm{Ab}$ and $\mathrm{Bb}$ showed $\mathrm{C}_{x}$ cellulase and cellobiase activity in that they released glucose from $\mathrm{CM}$-cellulose and cellobiose. Component $\mathrm{Ba}$ showed only cellobiase 
activity, and components $\mathrm{Bc}$ and $\mathrm{Bd}$ only $\mathrm{C}_{x}$ cellulase activity. Component Ac had neither $\mathrm{C}_{x}$ cellulase nor cellobiase activity.

The activity of the various components was also examined using insoluble cellulose powder. Components were examined singly and in various combinations such that the original cellulase complex was reconstituted in a stepwise manner (Table I). Release of glucose from the cellulose was indicative of enzyme activity. All the components released glucose from insoluble cellulose, although to varying degrees. When the components were combined more glucose was released than when each was used alone.

\section{DISCUSSION}

Rhizoctonia lamellifera produced cellulolytic enzymes which enabled it to grow on both soluble and insoluble forms of cellulose, releasing glucose as an end-product. Culture filtrates exhibited both $\mathrm{C}_{x}$ cellulase and cellobiase activities. The ability of the organism to use insoluble cellulosic substrates as sole carbon source is indicative of $\mathrm{C}_{1}$ cellulase production (Selby \& Maitland, 1967; Whitney et al., 1969).

After separation on Sephadex G-75, the two components, A and B, still exhibited both $C_{x}$ cellulase and cellobiase activities. Thus although chromatography on Sephadex G-75 separated the high molecular weight component (A) from the low molecular weight one (B), it failed to separate components with cellobiase activity from those with $\mathrm{C}_{x}$ cellulase activity. Ion-exchange chromatography (Olutiola \& Ayres, 1973) was used to separate cellobiases from $\mathrm{C}_{x}$ cellulases.

Components $\mathrm{Aa}, \mathrm{Ab}$ and $\mathrm{Bb}$ degraded $\mathrm{CM}$-cellulose and cellobiose, and thus showed $\mathrm{C}_{x}$ cellulase and cellobiase activities. Component $\mathrm{Ba}$ only degraded cellobiose and had no activity on CM-cellulose. Thus, this component seems to be a separated form of cellobiase, completely free from $\mathrm{C}_{x}$ cellulase activity. Components $\mathrm{Bc}$ and $\mathrm{Bd}$ degraded $\mathrm{CM}$-cellulose but not cellobiose, and therefore represent a cellobiase-free form of $\mathrm{C}_{x}$ cellulase.

Component Ac has a distinct characteristic in that, although it could not break down soluble celluloses, it hydrolysed insoluble cellulose releasing glucose. This component therefore resembles the Aa component of Olutiola \& Ayres (1973) and the $\mathrm{C}_{1}$ component of Selby \& Maitland (1967), but differs from the $\mathrm{C}_{1}$ of Li, Flora \& King (1965) and Wood (I968) because of its inability to degrade soluble cellulosic substrates.

When some of the components were combined, they showed synergistic effects (particularly when Ac was present). Synergism between separated components has been reported for a number of fungi (Selby \& Maitland, 1967; Umeruzike, 1970; Olutiola \& Ayres, 1973).

Culture filtrates of $R$. lamellifera contain high and low molecular weight proteins which exhibit differences in substrate specificity. The ability of $R$. lamellifera to produce such a system of cellulolytic enzymes means that the organism is equipped with enzymes to attack cellulose at different stages in its degradation from the crystalline form to the simpler, soluble forms which can be absorbed and utilized by the organism.

The disintegration of the cortical cells of infected tissues (Small, 1928; Robertson, 1959) strongly suggests that cellulase enzymes may play a role in pathogenicity. The importance of cellulolytic enzymes in pathogenicity has been indicated by other workers (Whitney et al., 1969; Umeruzike, 1970; Wood, 1968; Olutiola, 1972).

I wish to acknowledge the help of Mr Rajagopalan of the Nigerian Institute for Oil Palm Research for supplying the isolate, and Mr Cole and Dr Zoberi for the interest shown in the project. This work was supported by a grant (14.2590) from the University of Ife. 


\section{REFERENCES}

ANDREws, P. (1964). Estimation of the molecular weights of proteins by Sephadex gel-filtration. Biochemical Journal 9r, 222-233.

Flodin, P., Gelotte, B. \& Porath, J. (1960). A method for concentrating solutes of high molecular weight. Nature, London 188, 493-494.

LI, L. H., FLORA, K. M. \& KING, K. W. (1965). Individual roles of cellulase components derived from Trichoderma viride. Archives of Biochemistry and Biophysics III, 439-447.

Lowry, O. H., Rosebrough, N. J., FarR, A. L. \& RANDALl, R. J. (195I). Protein measurement with the Folin phenol reagent. Journal of Biological Chemistry I93, 265-275.

MILlER, G. L. (1959). Use of dinitrosalicylic acid reagent for determination of reducing sugar. Analytical Chemistry 3x, 426-428.

Olutiola, P. O. (1972). Aspects of carbohydrate physiology of Rhynchosporium secalis. Ph.D. thesis, University of Lancaster.

Olutiola, P. O. \& AYRes, P. G. (1973). A cellulase complex in culture filtrates of Rhynchosporium secalis. Transactions of the British Mycological Society 60, 273-282.

ROBERTSON, J. S. (1959). Blast disease of the oil palm: its cause, incidence and control in Nigeria. Journal of the West African Institute for Oil Palm Research 2, 310-330.

SelBY, K. \& MAITLAND, C. C. (1965). The fractionation of Myrothecium verrucaria cellulase by gel-filtration. Biochemical Journal 94, 578-583.

Selby, K. \& MaItLand, C. C. (I967). The cellulase of Trichoderma viride. Separation of the components involved in the solubilization of cotton. Biochemical Journal ro4, 716-724.

Small, W. (1928). The parasitism of Rhizoctonia batalicola (Taub.) Butl. and other fungi. Tropical Agriculturist 20, 21 5-227.

UMERUZIKE, G. M. (I970). Cellulose and $\beta$-glucosidase components in culture filtrates from Botryodiplodia theobromae Pat. Journal of Experimental Botany 21, 639-650.

WhITAKER, J.R. (1963). Determination of molecular weights of proteins by gel-filtration on Sephadex. Analytical Chemistry 35, 1950-1953.

Whitney, P., Chapman, J. M. \& Heale, J. B. (1969). Carboxymethylcellulase production by Verticillium albo-atrum. Journal of General Microbiology 56, 215-225.

Wood, T. M. (1968). Cellulolytic enzyme system of Trichoderma koningii. Separation of components attacking native cotton. Biochemical Journal ro9, 217-227.

Woorton, I. D. P. (1964). Microanalysis in Medical Biochemistry. London: Churchill. 